\title{
SUBSTITUSI TEPUNG TERIGU DENGAN TEPUNG KACANG HIJAU DALAM PENGOLAHAN MIE KERING
}

\author{
Sriyanto, S.TP ${ }^{(1)}$ dan Mulono Apriyanto, S.TP., MP ${ }^{(2)}$ \\ ${ }^{(1)}$ Alumni Teknologi Pangan FAPERTA UNISI \\ ${ }^{(2)}$ Dosen Teknologi Pangan FAPERTA UNISI
}

\begin{abstract}
Abstrak
Tujuan penelitian ini adalah untuk mengetahui karakteristik mie dari pencampuran tepung terigu dengan penambahan bahan tepung kacang hijau yang digunakan. Pencampuran bahan, penggilingan, pencetakan, pengukusan $\left(100{ }^{0} \mathrm{C}\right.$ selama 12 menit). Pendinginan (15 menit)dan menghasilkan mie. Penambahan tepung kacang hijau dengan berbagai variasi yaitu, 80\% tepung kacang hijau, 20\% tepung terigu, $70 \%$ tepung kacang hijau, 30\% tepung terigu, $60 \%$ tepung kacang hijau $40 \%$ tepung terigu dan 50\% tepung kacang hijau 50\% tepung terigu dan dilakukan 4 kali ulangan.

Untuk analisa dilakukan untuk menetukan kadar protein, kadar abu, kadar air, penilaian organoleptik meliputi warna mie, tekstur mie, aroma mie, rasa mie dan kekenyalan mie. Hasil penelitian menunjukkan bahwa kombinasi perlakuan penambahan tepung kacang hijau 50\% tepung kacang hijau dan 50\% tepung terigu mendapatkan hasil yang baik, semakin tinggi volume tepung terigu semakin baik pula mie yang dihasilkan.
\end{abstract}

Kata kunci : kacang hijau, mie kering, terigu

\section{PENDAHULUAN}

Mie merupakan salah satu jenis makanan yang terbuat dari satu pasta yang dicetak memanjang yaitu benang. Mie cukup digemari dan semakin populer di masyarakat, hal ini tidak hanya disebabkan oleh rasanya yang enak dan nilai gizinya yang relatif tinggi, juga dikarenakan cara penyajiannya yang mudah dan praktis, disamping itu produk pangan yang menggunakan mie sebagai bahan bakunya semakin beragam, diantaranya yaitu bakso, miso dan lain-lain.

Selama ini mie dibuat dengan tepung terigu, namun biasa disubsitusikan dengan tepung lain yang mempunyai komposisi hampir sama dengan tepung terigu, yaitu tepung kacang hijau yang mengandung karbohidrat.

Alternatif bahan baku yang dapat digunakan sebagai bahan pencampuran di dalam pembuatan mie adalah tepung kacang hijau. Kacang hijau banyak dibudidayakan di Indonesia. Pada tahun 2008 produksi kacang hijau di indonesia mencapai 298,06 ribu ton (Anonim, 2009). Kacang hijau mengandung protein yang sifatnya sama dengan tepung terigu, kandungan protein kacang hijau cukup tinggi, yaitu sekitar $24 \%$ dan selain itu, kacang hijau memiliki kelebihan di banding kacang - kacangan lain, yaitu tripsin inhibitornya sangat rendah, paling mudah dicerna dan paling 
kecil memberi pengaruh flatulensi atau kembung (Payumo,1978).

Beberapa penelitian yang telah dilakukan dalam pengolahan mie diantaranya adalah pengolahan mie basah dengan tepung terigu dapat subtitusikan dengan pati sagu, adapun perlakuan dalam pengolahan tepung terigu yang disubtitusi dengan pati sagu adalah dengan perlakuan, tepung terigu $100 \%$, pati sagu $10 \%$ dan tepung terigu $90 \%$, pati sagu $20 \%$ dan tepung terigu $80 \%$, dan pati Sagu $30 \%$ dan tepung terigu $70 \%$, dan hasil terbaik untuk parameter kadar air, kadar protein, warna aroma dan kekenyalan diperoleh pada perlakuan (Pati sagu 10\% dan tepung terigu $90 \%$ ), sedangkan hasil terbaik untuk parameter kadar pati diperoleh pada perlakuan (pati sagu $30 \%$ dan tepung terigu 70\%) (Subarjo 2012). Berdasarkan uraian diatas maka penulis telah melakukan penelitian dengan judul Karakteristik Mie dari Pencampuran Tepung Terigu dengan Tepung Kacang Hijau (Vigna radiate L).

\section{Perumusan Masalah}

Bahan baku yang biasa digunakan di dalam pembuatan mie adalah tepung terigu, tetapi tepung terigu ini sebenarnya dapat dicampur dengan bahan lain yang mempunyai sifat sama dengan terigu yaitu sagu, tepung ubi, dan tepun kacang hijau. Beberapa penelitian yang telah dilakukan didalam pengelolaan mie diantaranya adalah pengolahan mie basah dengan tepung terigu dapat subtitusikan dengan pati sagu, dan pengolahan mie basah dengan tepung terigu dapat disubtitusi dengan tepung ubi kayu, pengolahan tepung terigu yang disubtitusi dengan pati sagu. Sedangkan pembuatan mie yang tepung terigunya disubtitusi dengan tepung kacang hijau belum pernah dilakukan untuk itu telah dilakukan penelitian dengan judul "Karakteristik Mie dari Pencampuran Tepung Terigu dengan Tepung Kacang Hijau”.

\subsection{Tujuan Penelitian}

Tujuan penelitan ini adalah untuk mengetahui karakteristik mie dari pencampuran tepung terigu dengan tepung kacang hijau Vigna radiata $\mathrm{L}$ yang tepat dalam pengolahan mie.

\section{Manfaat Penelitian}

adalah:

Manfaat dari penelitian ini

1. Hasil penelitian dapat memberikan informasi mengenai penggunaan tambahan tepung kacang hijau sebagai pencampur tepung non terigu pada mie komersial.

2. Diharapkan dapat meningkatkan kualitas mie yang telah ada sehingga memberikan nilai tambah secara ekonomis.

\section{METODOLOGI PENELITIAN}

\section{Bahan}

Bahan yang digunakan pada penelitian ini adalah tepung terigu segi tiga biru dibeli di toko berkat, tepung kacang hijau dibuat sendiri, soda abu, garam, air, cuka dan telur. Bahan kimia yang digunakan pada penelitian ini adalah $\mathrm{CuSO}_{4}, \quad \mathrm{~K}_{2} \mathrm{SO}_{4} \mathrm{Se}$, akuades, $\mathrm{NaOH} 50 \%, \mathrm{H}_{3} \mathrm{BO}_{3}$, Indikator tashiro, HCLO, $1 \mathrm{~N}, \mathrm{NaOH} 4 \mathrm{~N}$, Larutan luff, $\mathrm{H}_{2} \mathrm{SO}_{4} 21 \%, \mathrm{Kl} 20 \%, \mathrm{Na} 2 \mathrm{~S}_{2} \mathrm{O}_{3} 0,1 \mathrm{~N}$, $\mathrm{K}_{2} \mathrm{Cr}_{2} \mathrm{O}_{70}, 1 \mathrm{~N}$ dan amilum.

\section{Alat \\ Alat yang digunakan dalam penelitian ini adalah ayakan, ampia, timbangan, sendok pengaduk, pisau, cawan proslen, oven, desikator, labu kjeldahl, labu ukur dan erlenmayer.}




\section{Metode Penelitian}

Rancangan yang digunakan di dalam penelitian ini adalah Rancangan Acak Lengkap (RAL) yang terdiri dari 4 perlakuan dan setiap perlakuan di ulang sebanyak 3 kali, sehingga diperoleh pola perlakuan 4 x 3 dengan jumlah 12 perlakuan. Adapun perlakuan pencampuran tepung terigu dengan tepung kacang hijau (Vigna radiate $\mathrm{L}$ ) dalam pembuatan mie adalah
A. Tepung Terigu $20 \%$ dan tepung kacang hijau $80 \%$
B. Tepung Terigu $30 \%$ dan tepung kacang hijau $70 \%$

C. Tepung Terigu $40 \%$ dan tepung kacang hijau $60 \%$

D. Tepung Terigu $50 \%$ dan tepung kacang hijau $50 \%$

Data-data yang diperoleh dari setiap perlakuan di analisis secara statistik menggunakan program statistix 8. Apabila hasil yang diperoleh berbeda nyata atau $\mathrm{F}$. hitung lebih besar dari $\mathrm{F}$ tabel maka dilakukan uji lanjut dengan metode Beda Nyata Jujur (BNJ). Kombinasi perlakuan dapat dilihat pada Tabel 1.

Tabel 3. Kombinasi Perlakuan Pada Pengolahan Mie dengan Pencampuran Tepung Terigu dengan Tepung Kacang Hijau.

\begin{tabular}{|c|c|c|c|c|}
\hline Ulangan & $\begin{array}{c}\text { A } \\
\text { (Tepung terigu } \\
20 \% \text { Tepung } \\
\text { Kacang Hijau } \\
80 \% \text { ) }\end{array}$ & $\begin{array}{c}\text { B } \\
\text { (Tepung terigu } \\
30 \% \text { Tepung } \\
\text { Kacang Hijau } \\
70 \%) \text { ) }\end{array}$ & $\begin{array}{c}\mathrm{C} \\
\text { (Tepung terigu } \\
40 \% \text { Tepung } \\
\text { Kacang Hijau } \\
60 \% \text { ) }\end{array}$ & $\begin{array}{c}\text { D } \\
\text { (Tepung terigu } \\
50 \% \text { Tepung } \\
\text { Kacang Hijau } \\
50 \% \text { ) }\end{array}$ \\
\hline 1 & $\mathrm{~A} 1_{1}$ & $\mathrm{~B} 2_{1}$ & $\mathrm{C} 3_{1}$ & $\mathrm{D} 4_{1}$ \\
\hline 2 & $\mathrm{~A} 1_{2}$ & $\mathrm{~B} 2_{2}$ & $\mathrm{C} 3_{2}$ & $\mathrm{D} 4_{2}$ \\
\hline 3 & $\mathrm{~A} 1_{3}$ & $\mathrm{~B} 2_{3}$ & $\mathrm{C} 3_{3}$ & $\mathrm{D} 4_{3}$ \\
\hline
\end{tabular}

Ket : A : Tepung kacang hijau $80 \%$ dan tepung terigu $20 \%$

B : Tepung kacang hijau $70 \%$ dan tepung terigu $30 \%$

C : Tepung kacang hijau $60 \%$ dan tepung terigu $40 \%$

$\mathrm{D}$ : Tepung kacang hijau $50 \%$ dan tepung terigu $50 \%$

Pembuatan Tepung Kacang Hijau

Pembuatan tepung kacang hijau

Vigna radiata (L) rebus menggunakan metode Astawan (2005) sebagai berikut :

1. Sortasi

Sortasi bertujuan untuk memilih mutu kacang hijau yang baik dan layak untuk dijadikan tepung kacang hijau dalam pengolahan mie.

2. Pencucian

Pencucian bertujuan untuk menghilangkan kotoran dan benda asing yang terdapat pada kacang hijau, seperti debu, kulit buah kacang yang masih tersisa pada kacang hijau.

3. Perebusan

Perebusan bertujuan untuk memudahkan proses pembuangan kulit ari, perebusan ini dilakukan selama 20 menit dengan suhu $100^{\circ} \mathrm{C}$

4. Pengupasan

Pengupasan bertujuan untuk menghilangkan kulit ari.

5. Pengeringan

Pengeringan dengan menggunakan cabinet driyer bertujuan untuk menguragi kadar air agar memudahkan dalam proses 
penggilingan. Pengeringan dengan Cabinet driyer pada suhu $70{ }^{0} \mathrm{C}$ selama 7 jam.

6. Penggilingan

Penggilingan bertujuan untuk menghancurkan biji kacang hijau agar menjadi tepung.

7. Pengayakan

Pengayakan bertujuan untuk mendapatkan ukuran partikel tepung yang seragam, pengayakan dengan menggunakan ayakan 80 mesh.

\section{Pembuatan Mie}

Menurut

Astawan,

(1999)

tahapan pembuatan mie dengan campuran tepung terigu dengan tepung kacang hijau adalah sebagai berikut :

1. Persiapan bahan

a. Tepung terigu yang digunakan adalah tepung terigu medium (segitiga biru) yang dibeli dari toko berkat tembilahan.

b. Tepung kacang hijau yang diperoleh dari hasil pembuatan tepung kacang yang sebelumnya telah dilakukan sortasi.

c. Soda abu yang digunakan adalah soda abu yang diperoleh dari warung.

d. Garam yang digunakan dalam pembuatan mie adalah garam yang dibeli dari warung.

e. Air yang digunakan adalah air mineral.

2. Pencampuran Bahan dan pembuatan adonan

Semua bahan yang digunakan dicampurkan yaitu : Tepung sebanyak 1000 gram sesuai dengan perlakuan (20\% tepung terigu dan tepung kacang hijau untuk perlakuan I, tepung kacang hijau $70 \%$ dan tepung terigu $30 \%$ untuk perlakuan II, tepung kacang hijau $60 \%$ dan tepung terigu $40 \%$ untuk perlakuan III, tepung kacang hijau 50\% dan tepung terigu $50 \%$ untuk perlakuan IV).
Kemudian masing-masing perlakuan ditambah soda abu $1,1 \%$, garam $0,1 \%$, air $37 \%$, cuka $0,1 \%$ dan telur 3 butir. Semua bahan tersebut dicampur secara manual hingga terbentuk adonan yang sempurna yang ditandai dengan tidak lengketnya adonan pada tangan dan dinding permukaan baskom yang digunakan sebagai tempat pembuatan adonan kemudian adonan ditekan-tekan sampai permukaan adonan halus.

\section{Penggilingan}

Adonan kemudian dibentuk menjadi bulatan-bulatan kecil lalu digiling menggunakan ampia membentuk lembaran, dilipat 2 kali dan digiling kembali. Proses ini dilakukan beberapa kali sampai permukaan lembaran adonan betul betul halus. Lembaran adonan diistirahatkan selama kurang lebih 15 menit agar proses glatinisasi lebih optimal, setelah itu adonan digiling lagi dengan ketebalan $1,5 \mathrm{~mm}$ sampai dengan $2 \mathrm{~mm}$ atau penggilingan ini dilakukan dari ketebalan (set) 1 sampai 4.

\section{Pencetakan}

Lembaran adonan dipotong dengan menggunakan ampia membentuk tali atau benang-benang. Sampai pada tahap ini mie yang dihasilkan adalah mie mentah, kemudian diistirahatkan selama kurang lebih 30 menit supaya proses glatinisasinya optimal.

5. Pengukusan

Mie dari hasil pemotongan tersebut dikukus dalam dandang pengukus pada suhu $100^{\circ} \mathrm{C}$ selama kurang lebih 12 menit.

\section{Pendinginan}

Mie dipindahkan ke dalam nampan plastik lalu didinginkan dengan cara didiamkan selama 15 menit. 


\section{HASIL DAN PEMBAHASAN}

\section{Kadar Air Mie}

Kadar air adalah persentase kandungan air suatu bahan yang dapat dinyatakan berdasarkan berat basah (wet basis) atau berdasarkan berat (dry basis). Kadar air berat basah mempunyai batas maksimum teoritis sebesar 100 persen, sedangkan kadar air berdasarkan berat dapat lebih dari 100 persen. (Syarif dan Halid, 1993). Rata-rata kadar air mie setelah diuji lanjut disajikan pada Tabel 1.

Tabel 1. Rata-rata Kadar Air Mie

\begin{tabular}{|l|l|}
\hline Perlakuan & Rata - rata (\%) \\
\hline A (Tepung kacang hijau 80\% dan Tepung Terigu 20\%) & 28.867 a \\
B (Tepung kacang hijau 70\% dan Tepung Terigu 30\%) & $27.457 \quad$ b \\
C (Tepung kacang hijau 60\% dan Tepung Terigu 40\%) & $26.570 \quad$ c \\
D (Tepung kacang hijau 50\% dan Tepung Terigu 50\%) & $24.930 \quad$ d \\
\hline
\end{tabular}

Keterangan : Angka-angka yang diikuti huruf kecil yang berbeda pada kolom yang sama berbeda nyata menurut uji lanjut Tukey pada taraf $1 \%$.

Pada Tabel 1 terlihat pada perlakuan bahwa semakin tinggi substitusi tepung terigu maka semakin rendah pula kadar air yang terdapat pada mie, hal ini dipengaruhi oleh sifat dari kedua jenis tepung tersebut yaitu tepung terigu dan tepung kacang hijau. Jika dilihat dari nilai kadar air yang terkandung di dalam mie terlihat adanya perbedaan kadar air mie pada perlakuan dimana kadar air tertinggi terdapat pada perlakuan A (Kacang hijau $80 \%$ dan Tepung Terigu 20\%) dengan kadar air $28.867 \%$ dan terendah pada perlakuan D (Kacang hijau 50\% dan Tepung Terigu $50 \%$ ) dengan kadar air $24.930 \%$.

Dari tabel 1 dapat dilihat bahwa kadar air dari perlakuan mie tidak sesuai dengan standar kadar air mie menurut syarat mutu mie SNI 0178-90, dimana syarat mutu mie untuk mutu 1 kadar air maksimum $8 \%$ sedangkan untuk mutu kadar air mutu 2 kadar mie maksimum $10 \%$.

Air pada adonan mie berasal dari air yang terkandung pada tepung yang digunakan dan air yang ditambahkan pada saat pembuatan adonan. Dengan penggunaan lebih dari satu jenis tepung dan beraneka macam persentase tepung yang ditambahkan, maka kadar air dan penyerapan air akan berbeda pula. Oleh karena itu, jumlah air yang ditambahkan pada saat pembuatan adonan mie disesuaikan dengan water holding capacity bahan sehingga diperoleh kadar air dan sifat konsistensi adonan yang sama. Selain itu setelah mie dicetak dilakukan proses perebusan menggunakan air sehingga kadar air mie akan bertambah.

Kadar air mie tepung terigu berbeda nyata dengan mie campuran tepung terigu dan tepung kacang hijau. WHC pada tepung kacang hijau lebih besar daripada tepung terigu. Oleh karena itu substitusi tepung terigu dengan tepung kacang hijau semakin meningkat persentase tepung kacang hijau maka akan meningkatkan penyerapan air ketika perebusan sehingga mie campuran tepung terigu dan tepung kacang hijau ini mempunyai kadar air yang lebih besar.

Fraksi amilosa yang bersifat lebih menyebabkan lebih banyak menyerap air selama proses pengolahan dan akan mengalami proses glatinisasi. 
Glatinisasi merupakan peristiwa terbentuknya gel dari kacang karena terkena panas yang semakin meningkat dan menyebabkan air yang terperangkap di dalam kacang semakin banyak (Pudjiatmoko, 2007).

Fraksi amilosa menyebabkan bahan lebih bersifat, sehingga lebih mudah menyerap air. Amilosa akan mempengaruhi sifat viskositas seperti kacang dalam air, sehingga dapat menyerap air sampai sekitar empat kali lebih besar yang menyebabkan viskositas meningkat (Royaningsih.dan Pangloli, 1988).

\section{Kadar Abu Mie}

Kadar abu merupakan campuran dari komponen anorganik atau mieneral yang terdapat pada suatu bahan pangan. Bahan pangan terdiri-dari $96 \%$ bahan anorganik dan air, sedangkan sisanya merupakan unsur-unsur mineral, unsur juga dikenal sebagai zat organik atau kadar abu. Kadar abu tersebut dapat menunjukan total mieneral dalam suatu bahan pangan (Apriyantono et al, 1998).

Hasil sidik ragam dari perlakuan substitusi tepung terigu dengan kacang hijau dalam pembuatan mie menunjukkan berbeda nyata terhadap parameter kadar abu. Rata-rata kadar abu mie setelah di uji lanjut disajikan pada Tabel 2.

Tabel 2. Rata-rata Kadar Abu Mie

\begin{tabular}{|l|l|}
\hline Perlakuan & Rata - rata (\%) \\
\hline D (Tepung kacang hijau 50\% dan Tepung Terigu 50\%) & $1.3400 \mathrm{a}$ \\
C (Tepung kacang hijau 60\% dan Tepung Terigu 40\%) & $1.3300 \mathrm{a}$ \\
B (Tepung kacang hijau 70\% dan Tepung Terigu 30\%) & $1.2667 \mathrm{~b}$ \\
A (Tepung kacang hijau 80\% dan Tepung Terigu 20\%) & $1.2267 \mathrm{c}$ \\
\hline
\end{tabular}

Keterangan : Angka-angka yang diikuti huruf kecil yang berbeda pada kolom yang sama berbeda nyata menurut uji lanjut Tukey pada taraf $1 \%$.

Data pada Tabel 2 menunjukan bahwa kadar abu dari setiap perlakuan menunjukan perbedaan yang nyata tetapi tidak terlalu jauh, hal ini disebabkan karena kandungan abu (mieneral) yang terdapat dalam kacang hijau sangat kecil yaitu hanya $0,21 \%$ sedangkan pada tepung terigu kandungannya kadar abu yaitu $1,23 \%$, sehingga substitusi kacang hijau hingga $30 \%$ tidak menimbulkan pengaruh yang nyata terhadap kadar abu mie . Kadar abu mie berasal bahanbahan yang digunakan dalam proses pembuatan mie .

Dari Tabel 2 dapat dilihat nilai terendah dari kadar abu terdapat pada perlakuan A (Kacang hijau $80 \%$ dan Tepung Terigu 20\%) dengan kadar abu
$1,2267 \%$ dan tertinggi pada perlakuan D (Kacang hijau 50\% dan Tepung Terigu $50 \%$ ) dengan kadar abu $1,3400 \%$. Kandungan kadar abu sangat ditentukan oleh persentase subsitusi tepung dimana semakin tinggi jumlah persentasi tepung terigu maka kadar abu semakin meningkat, hal ini diduga karena pengaruh jumlah kandungan kadar abu pada tepung terigu cukup tinggi.

Kadar abu merupakan salah satu parameter pada mie karena berkorelasi dengan warna mie. Semakin besar kadar abu, maka warna mie juga akan semakin gelap. Warna gelap ini tidak bisa diterima oleh konsumen. Kadar abu mie yang dipersyaratkan dalam SNI tidak melebihi 3\%. Kadar abu 
mie substitusi tepung kacang hijau dari semua perlakuan kurang dari $2 \%$ sehingga masih memenuhi persyaratan SNI.

Kadar abu menunjukan jumlah bahan mieneral yang dikandung bahan. Menurut Royaningsih dan Pangloli (1988) kadar abu merupakan komponen mieneral yang tidak menguap pada saat pembakaran atau pemiejaran senyawasenyawa organik.

\section{Kadar Protein Mie}

Hasil sidik ragam dari perlakuan substitusi tepung terigu dengan kacang hijau dalam pembuatan mie berpengaruh nyata terhadap parameter kadar protein. Rata-rata kadar protein mie setelah di uji lanjut disajikan pada Tabel 3.

Tabel 3. Rata-rata Kadar Protein Mie

\begin{tabular}{|l|l|}
\hline Perlakuan & Rata - rata (\%) \\
\hline D (Tepung kacang hijau 50\% dan Tepung Terigu 50\%) & 16.360 a \\
C (Tepung kacang hijau 60\% dan Tepung Terigu 40\%) & $15.220 \quad$ b \\
B (Tepung kacang hijau 70\% dan Tepung Terigu 30\%) & $13.840 \quad \mathrm{c}$ \\
A (Tepung kacang hijau 80\% dan Tepung Terigu 20\%) & $12.537 \quad$ d \\
\hline
\end{tabular}

Keterangan : Angka-angka yang diikuti huruf kecil yang berbeda pada kolom yang sama berbeda nyata menurut uji lanjut Tukey pada taraf $1 \%$.

Data pada Tabel 3 menunjukan bahwa perlakuan D (Kacang hijau $50 \%$ dan Tepung Terigu 50\%) dengan kadar protein $16.360 \%$ merupakan perlakuan yang kadar proteinnya tertinggi sedangkan kadar protein terendah pada perlakuan A (Kacang hijau $80 \%$ dan Tepung Terigu 20\%) dengan kadar protein $12,537 \%$, dimana semakin besar subsitusi tepung kacang hijau maka semakin kecil pula kadar protein yang diperoleh. Dari data diatas dapat disimpulkan penurunan kadar protein seiring dengan peningkatan substitusi tepung terigu.

Hasil penelitian menunjukan bahwa adanya perbedaan kadar protein dari kedua jenis tepung tersebut yaitu semakin tinggi substitusi kacang hijau otomatis akan mengurangi proporsi tepung terigu yang secara tidak langsung akan mengurangi kandungan protein terdapat pada mie yang dihasilkan.

Kadar protein tertinggi pada perlakuan diperoleh pada perlakuan D
(Kacang hijau 50\% dan Tepung Terigu $50 \%$ ) dengan kadar protein $16.360 \%$ dan terendah pad perlakuan A (Kacang hijau $80 \%$ dan Tepung Terigu 20\%) dengan kadar protein $12,537 \%$ hal ini disebabkan tepung terigu.

Kadar protein merupakan salah satu penentu kualitas mie karena adanya interaksi protein terigu dengan air pada pembuatan mie akan menghasilkan matriks gluten yang menentukan tingkat fleksibilitas mie. Selain itu, kandungan protein juga menentukan nilai gizi mie . Menurut SNI 0178-90 kadar protein untuk mie mutu I minimal $11 \%$ dan mutu II minimal 8\%. Dari tabel 3 dapat dilihat bahwa untuk semua perlakuan memenuhi persyaratan untuk kadar protein menurut standar SNI.

\section{KESIMPULAN DAN SARAN}

\section{Kesimpulan}

Berdasarkan hasil penelitian ini dapat disimpulkan sebagai berikut : 
1. Campuran tepung terigu dengan tepung kacang hijau dalam pembuatan mie berpengaruh nyata terhadap kadar air, kadar protein, kadar abu, dan nilai organoleptik warna, aroma kekenyalan mie, tekstur dan rasa.

2. Hasil terbaik untuk parameter kadar air, kadar protein, warna, aroma dan kekenyalan diperoleh pada perlakuan D (Kacang hijau 50\% dan Tepung Terigu 50\%) dengan kadar air $24,930 \%$, kadar protein $16,360 \%$, warna 4,1267, aroma 3,3200 dan kekenyalan 2,7833. Sedangkan hasil terbaik untuk parameter kadar abu diperoleh pada perlakuan A (Tepung kacang hijau $80 \%$ dan Tepung Terigu $20 \%$ ) yaitu $1,2267 \%$.

3. Secara umum hasil terbaik untuk campuran tepung terigu dengan kacang hijau dalam pembuatan mie diperoleh pada perlakuan D (Kacang hijau 50\% dan Tepung Terigu 50\%).

\section{Saran}

Saran yang diperlukan pada penelitian ini adalah :

1. Untuk memperoleh mie yang baik dengan menggunakan campuran tepung terigu dan tepung kacang hijau, dianjurkan menggunakan komposisi kacang hijau 50\% dan tepung terigu $50 \%$.

2. Perlu adanya penelitian formulasi berbeda dengan menggunakan campuran yang berbeda.

\section{DAFTAR PUSTAKA}

Aini,N., H.Dwiyanti dan R.Setyawati. 2003. Tepung Ubi Jalar sebagai Bahan Baku Pembuatan Mie dengan Suplementasi Oalahan Kedelai dan Variasi Sumber Pengemulsi.Jurnal Pembangunan
Pedesaan. Volume 3. Nomor 3. Purwakarto.

Anna-Poedjiadi. 1994. Dasar-dasar Biokimia. UI Press. Jakarta.

Anonim. 2009. Statistik Indonesia. Biro Statistik Indonesia. www.bps.go.id Akses Tanggal 10 Januari 2013.

Apriantono, A; D. Fardiaz; N.L. Puspitasari; Sedarnawati; dan S. Budiyanto.. $1989 . \quad$ Analisa Pangan. Pusat Antar Universitas. Institut Pertanian Bogor. Bogor.

Astawan, M. 1999. Membuat Mie dan Bihun. Penebar Swadaya. Jakarta.

Astawan, M. 2005. Membuat Mie dan Bihun. Penebar Swadaya. Jakarta.

Bayu-Kenetro, dan Setyo-Hastuti. 2006. Ragam Produk Olahan Kacangkacangan. Debut Press. Yogyakarta.

Chang, R, Schiwmer, S. and Bare, H. K. 1977. Phytate Removal from Whole Dry Beans by Enzymatic Hydrolisis and Difussion. Journal of Food Science.

De Man, J. M. 1997. Princeples of Food Chemistry. The AVI Publishing Company Inc. Westport Connectitut.

Ertha-Martha-Intani. 2009. Subsitusi Sebagian Tepung Terigu Dengan Tepung Jagung(Zee Mays L) dan Tepung Ikan Tenggiri (Stolephorus Sp) pada Pembuatan Mie Basah. Skripsi S1. FTP UGM. Yogyakarta.

Haryanto, B. dan Pangloli. 1992. Potensi dan Pemanfaatan Sagu. Kanisius Yogyakarta.

Kartika, B,. P. Hastuti dan W. Supartono. 1988. Pedoman Uji Indrawi Bahan Pangan. Pusat Antar Universitas Pangan Dan 
Gizi. Universitas Gajah Mada. Yogyakarta.

Kristiani, N. 1996. Stabilitas Emulsi dan Sifat sensoris Sosis Daging Sapi dengan Binder Tepung Kacang Hijau. Skripsi S1 FTP UGM. Yogyakarta.

Payumo, M. E. 1978. The Potential of Mungbeen as a Protein Suplement for Child Feeding. The International Mungbean Symposium.

Rahmawati, L. 2009. Subsitusi Sebagian Tepung Terigu dengan Tepung Ubi Kayu dan Tepung Kacang Hijau Pada Pembuatan Mi Basah. UGM. Yogyakarta. Skripsi.

Rustandi, D. 2003. Memaksimalkan Pembuatan

Mie. www.wacanamitra.com. Diakes pada tanggal 28 Januari 2013.

Somaatmadja, S. 1993. Proses Sumber Daya Nabati Asia Tenggara II Kacang-kacangan. Gramedia Pustaka Umum. Jakarta.

Subarjo. 2012. Substitusi Tepung Terigu dengan Pati Sagu dalam Pengolahan Mie Kering. Skripsi S1. UNISI
Sudarmadji, S. et, al. 1997. Prosedur Analisa untuk Bahan Makanan dan Petanian. Liberty. Yogyakarta.

Suryo, et. al. 2002. Kajian senyawa asam fitat pada biji kacang hijau (Phaseolus aureus L) dan Senyawa antioksidan pada biji kacang hijau ((Phaseolus aureus $L)$, biji kacang buncis ((Phaseolus vulgaris L), dan biji kacang kapri (pisum sativum L) serta olahannya. Skripsi S1 FTP UGM. Yogyakarta.

Taub, T. A. and R. P. Singh. 1998. Food Storage Stability. CRC Press. USA.

Tengenjaya, B. 1979. Studies on the dephosphorilation of phytic acid in rice bran. Universitas of New South Wales. Sydney.

Winarno, F.G. 1997. Kimia Pangan dan Gizi. Jakarta : Gramedia Pustaka Utama. Wirakusumah, Emma. S. 1995. Buah dan Sayur Untuk Terapi. Jakarta : PT Penebar Swadaya. 